\title{
Presentation of
}

\section{Arndís Bergsdóttir}

Dr Arndís Bergsdóttir is a postdoctoral researcher, and project manager for Iceland, with HM Queen Margrethe II's and Vigdís Finnbogadóttir's Interdisciplinary Research Centre on Ocean, Climate and Society (ROCS) and a sessional teacher in Museum Studies at the University of Iceland. Arndís involvment with the Museum Studies

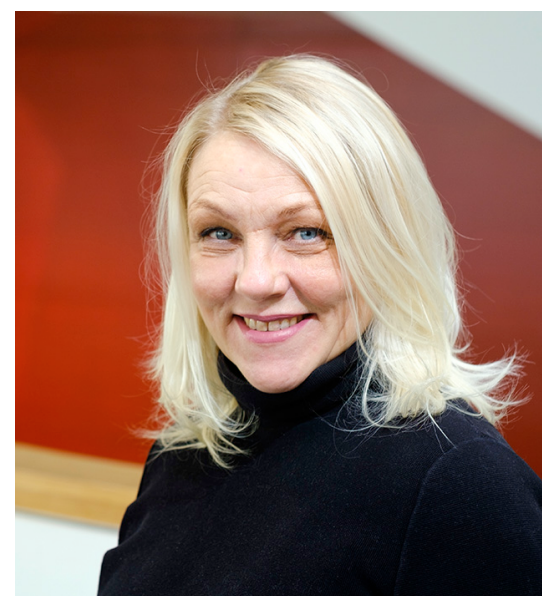

Arndís Bergsdóttir. Photo: Kristinn Ingvarsson, University of Iceland. programme at the Faculty of Sociology, Anthropology and Folkloristics has lasted for almost a decade and she is currently seated on the executive committee of the university's Research Center for Museum Studies. In addition to her teaching duties, Arndís has previously participated in a number of research projects, either as a postdoctoral researcher or contributor. The projects she has been involved in include: Disability before Disability, Mobilities and Transnational Iceland, and Favourite Things but all of these projects are Grant of Excellece projects at the University of Iceland. She has also been a member of Akureyri Art Museum's advisory board, and substitute member of the Icelandic Museum Association's board of directors. Her research interests include the complex constellations of intraactive relationships that equally generate grounds for research and powerful frameworks to approach matters of museums and heritage.

Arndís is especially interested in the transdisciplinarity inherent in museum and heritage studies and views them as productive ways to critically engage with the layered constellations of human and non-human relationships that comprise shared histories. Such relationalities are the underpinnings for her research within the interdisciplinary ROCS research center, but the center aims at combining research from the humanities/social sciences and natural sciences to increase understadings of the interaction between climate and the ecosystems of the ocean and their importance to culture and society in Iceland. Arndís is one of six postdoctoral researchers employed with ROCS. Her project Enmeshed climate/biosphere/human relationships in Iceland turns to the posthumanities and critical heritage studies to approach the multifaceted historical connections between ecosystem structure, climate development and the population in Iceland. Situated within museum and heritage studies her project reaches out to the natural sciences to underline 
companionships across disciplines with the aim of co-producing insights into the plurality of human/climate/biosphere relationships.

When working across disciplines to study the dynamic relationships inherent in multifaceted companionships Arndís draws on her research that, for the past decade, has tended to traverse the ingrained dichotomies that sustain marginalization and the exclusionary practices found in museums. Within the overarching frameworks of posthumanities and material feminisms her research has specifically attended to absences as relational becomings of matter. In fact, gendered absences in museums were a core issue in the Ph.D. thesis that she defended in August 2017. Her Ph.D. project began as a study of the roles women and their stories play in museum narratives and how these are represented. Yet, the sheer absences of women's lived lives and experiences that emerged in the study urged her to investigate these as noteworthy material phenomena that come into being through iterative and complex relationships. This resulted in her conceptualization of absencepresence; a tool that she has subsequently developed further in various research projects, for instance her postdoctoral research within the project Disability before Disablity.

At this time, two chapters about the absences and representations of disabled people in museums are forthcoming in a volume affiliated with the project Disability before Disability. Impending is also a book propsal where she draws on this work and her doctoral research to encompass and attend to a feminist museology through matters of absence. Arndís is delighted to join Nordisk Museologi and looks forward to working with the editorial team in future.

\author{
Dr Arndís Bergsdóttir \\ arndisbergs@hi.is \\ University of Iceland \\ Seemundargata 2 \\ IS - 102 Reykjavík
}

